\title{
Perancangan Dan Pembuatan Aplikasi Rekomendasi Jadwal Perkuliahan Pada Institut Informatika Indonesia Memanfaatkan Algoritma Genetika
}

\author{
Hermawan Andika, S.Kom., M.Kom. \\ Jurusan Teknik Informatika \\ Institut Informatika Indonesia \\ Jl. Raya Sukomanunggal Jaya 3, Surabaya \\ andi@ikado.ac.id
}

\begin{abstract}
ABSTRAK
Penjadwalan adalah sebuah proses pengambilan keputusan yang sering dilakukan di industri manufaktur maupun di industri yang bergerak di bidang pelayanan atau jasa. Persoalan penjadwalan berkaitan dengan pengalokasian sumber daya ke dalam tugas-tugas atau fungsi-fungsi tertentu. Begitu juga pada bidang edukasi di perguruan tinggi, penjadwalan mata kuliah merupakan kegiatan rutin yang dilakukan oleh setiap institusi pendidikan pada setiap awal semester. Hal ini termasuk kegiatan yang penting karena pelaksanaannya melibatkan banyak aspek yang berbeda tetapi saling berkaitan. Aspek-aspek yang harus dipertimbangkan antara lain keterbatasan ruang, jumlah ruang yang dapat digunakan untuk menyelenggarakan perkuliahan, keterbatasan kapasitas ruang, dan keterbatasan jam mengajar dosen. Untuk membantu mencari rekomendasi dari penjadwalan maka penulis membuat aplikasi "Rekomendasi Jadwal Perkuliahan” yang memanfaatkan algoritma genetika, yaitu algoritma yang menyelesaikan masalah dengan melakukan pemodelan mekanisme evolusi biologis. Kombinasi proses genetika yang digunakan adalah reproduksi,mutasi dan crossover. Sedangkan gen yang digunakan adalah hari, pertemuan, ruang kelas. Dan allele-nya berupa dosen dan matakuliah.
\end{abstract}

Kata Kunci : Rekomendasi, Penjadwalan, Algoritma Genetika

\section{PENDAHULUAN}

Penjadwalan merupakan sebuah proses pengambilan keputusan yang sering dilakukan di industri manufaktur maupun di industri yang bergerak di bidang pelayanan atau jasa. Persoalan penjadwalan berkaitan dengan pengalokasian sumber daya ke 
dalam tugas-tugas atau fungsi-fungsi tertentu. Tujuan penjadwalan adalah untuk mengoptimalkan satu atau beberapa tujuan.

Penjadwalan mata kuliah merupakan kegiatan rutin yang dilakukan oleh setiap institusi pendidikan pada setiap awal semester, begitu juga halnya dengan Institut Informatika Indonesia. Penjadwalan perkuliahan merupakan hal penting karena pelaksanaannya melibatkan banyak aspek yang berkaitan dan masing-masing memiliki prioritas yang berbeda. Aspek-aspek yang harus dipertimbankan antara lain keterbatasan ruang, jumlah ruang yang dapat digunakan untuk menyelenggarakan perkuliahan, keterbatasan kapasitas ruang, dan keterbatasan jam mengajar dosen. Semakin bertambahnya jumlah mata kuliah yang akan dijadwalkan, semakin kompleks persoalan penjadwalan yang dihadapi.

Algoritma Genetika merupakan algoritma pendekatan komputasional untuk menyelesaikan masalah yang dimodelkan dengan proses biologi dari evolusi. Keuntungan penggunaan Algoritma Genetika adalah dari kemudahan implementasi dan kemampuannya untuk menemukan solusi yang bagus dan cepat untuk masalah-masalah berdimensi tinggi. Penggunaan Algoritma Genetika untuk menyelesaikan seputar masalah penjadwalan telah banyak dipergunakan oleh para peneliti bidang ini.

Selama ini, penjadwalan yang dilakukan umumnya masih bersifat manual, dengan mengakomodasi keterbatasan-keterbatasan tersebut, namun belum mempertimbangkan sisi efisiensi baik dari sisi penggunaan ruang dan fasilitas yang ada maupun dari sisi kenyamanan bagi dosen maupun mahasiswa. Selain itu juga perlu diperhatikan efisiensi penggunaan ruang, yaitu perlunya pengalokasian ruang yang tepat bagi suatu mata kuliah berdasarkan kapasitas ruang dan beban utilitas ruang tersebut,sehingga perlu adanya aplikasi penjadwalan perkuliahan secara otomatis. Pada tugas akhir ini, penulis mencoba menyelesaikan masalah penjadwalan perkuliahan menggunakan Algoritma Genetika sebagai metode optimasinya.

\section{METODOLOGI PENELITIAN}

\section{Algoritma Genetika}

Algoritma genetika pertama kali diperkenalkan oleh John Holland pada tahun 1960-an sebagai algoritma berbasis populasi dengan pendekatan biologi yang lebih masuk akal dari pendekatan-pendekatan sebelumnya. Algoritma Genetika ini 
terinspirasi dari salah satu teori biologi yaitu evolusi biologis yang dikemukakan oleh Charles Darwin. Teori tersebut menyatakan bahwa individu-individu yang memiliki karakteristik yang baik berdasarkan kriteria-kriteria tertentu akan memiliki kemungkinan lebih besar untuk bertahan hidup dan bereproduksi serta menurunkan karakteristiknya kepada keturunan-keturunannya. Hal ini berlaku sebaliknya. Jika individu-individu yang memiliki karakteristik yang buruk maka secara perlahan-lahan akan tersingkir dari populasi.

Istilah-istilah yang digunakan pada Algoritma Genetika juga diambil dari istilah evolusi biologis. Istilah-istilah tersebut antara lain populasi, kromosom, gen, seleksi, mutasi, dan persilangan (crossover). Populasi merupakan kumpulan dari sejumlah individu. Pada alam ini, jumlah individu dalam populasi tidak sama untuk setiap generasi, namun pada Algoritma Genetika jumlah individu untuk setiap generasi selalu sama. Karakteristik-karkteristik individu tersimpan pada kromosom yang terdiri dari beberapa gen. Gen merupakan elemen-elemen dasar yang mencerminkan faktor genetik pada sebuah kromosom. Pada Algoritma Genetika satu individu diasumsikan sebagai sama dengan satu kromoson saja. Keberhasilan sebuah individu bertahan hidup ditentukan oleh seleksi. Meskipun individu dengan karakter yang buruk memiliki kemungkinan untuk bertahan, namun individu dengan karakter yang baik memiliki peluang lebih besar.

Algoritma Genetika memelihara populasi dari individu-individu. Untuk setiap individu, memiliki potensi untuk dijadikan solusi terhadap masalah yang ingin diselesaikan. Penilaian atau evaluasi untuk menentukan kualitas dari individu sebagai fitness. Beberapa individu dari populasi akan mengalami transformasi atau adaptasi yang disebabkan oleh operasi genetika. Hasil dari transformasi ini akan membentuk individu-individu baru.

Terdapat dua macam transformasi yaitu mutasi dan crossover (persilangan). Mutasi dapat menyebabkan terbentuknya individu-individu baru dengan membuat sebuah perubahan pada gen dari satu individu. Sedangkan crossover dapat menyebabkan terbentuknya individu-individu baru dengan mengkombinasikan bagianbagian dari dua individu. 
Individu-individu baru yang terbentuk dapat disebut juga sebagai offspring. Evaluasi fitness dilakukan terhadap individu-individu baru tersebut. Setelah itu, dilakukan proses seleksi untuk membentuk sebuah populasi baru dari offspring dan parent yang memiliki nilai fitness terbaik. Parent merupakan individu-individu yang bertindak sebagai orangt tua yang melahirkan offspring.

Terbentuknya offspring baru menandakan telah terjadi satu generasi dan dimulainya sebuah generasi baru. Proses tersebut diulang berkali-kali hingga jumlah tertentu. Pada generasi terakhir, Algoritma Genetika akan mendapatkan individuindividu terbaik yang harapannya akan mewakili solusi optimal untuk memecahkan masalah. Diagram alur sederhana dari Algoritma Genetika adalah seperti yang terdapat pada gambar berikut.

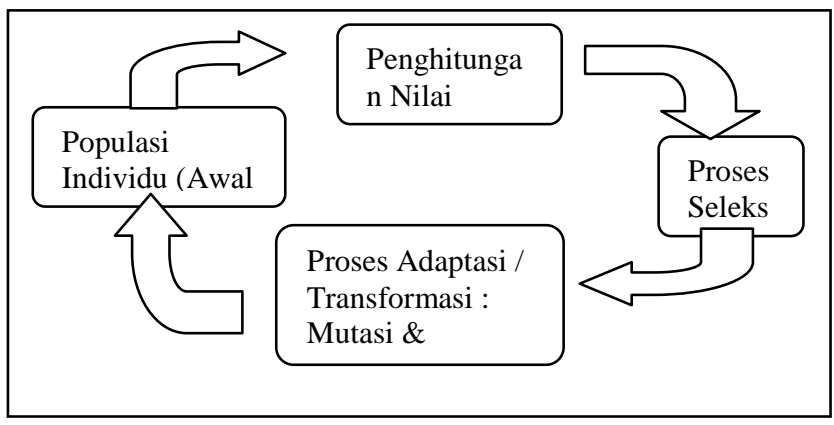

Setiap Individu pada populasi dianggap seperti sebuah kromosom. Analogi dari kromosom ini adalah rangkaian DNA manusia. Oleh karena itu seperti halnya rangkaian DNA, satu kromosom pada Algorima Genetika terdiri dari beberapa gen.

Representasi gen pada Algoritma Genetika ada bermacam-macam, namun yang cukup sering digunakan adalah representasi bilangan integer dan bilangan biner. Untuk representasi integer setiap gen pada kromosom diwakili oleh sebuah bilangan integer. Sedangkan pada representasi biner, gen pada kromosom diwakili oleh bilangan biner yang memiliki dua allele yaitu 0 dan 1 . Allele merupakan nilai yang mungkin untuk gen. Pada DNA manusia, terdapat empat allele yaitu A (Adenine), C (Cytosine), G (Guanine), dan T (Thymine).

\section{HASIL PEMBAHASAN}

Beradasarkan analisa sistem yang telah dilakukan maka didapatkan hasil akhir sebuah aplikasi yaitu Aplikasi Rekomendasi Penjadwalan Perkuliahan. 


\section{A. Diagram Alur Sistem}

Gambaran sistem bagaimana alur kerja dan interaksi antara sistem dengan user secara umum. Dimulai dari inputan apa saja yang dibutuhkan oleh sistem hingga penjadwalan berlangsung. Untuk gambaran lebih jelas dapat dilihat pada gambar use case diagram berikut

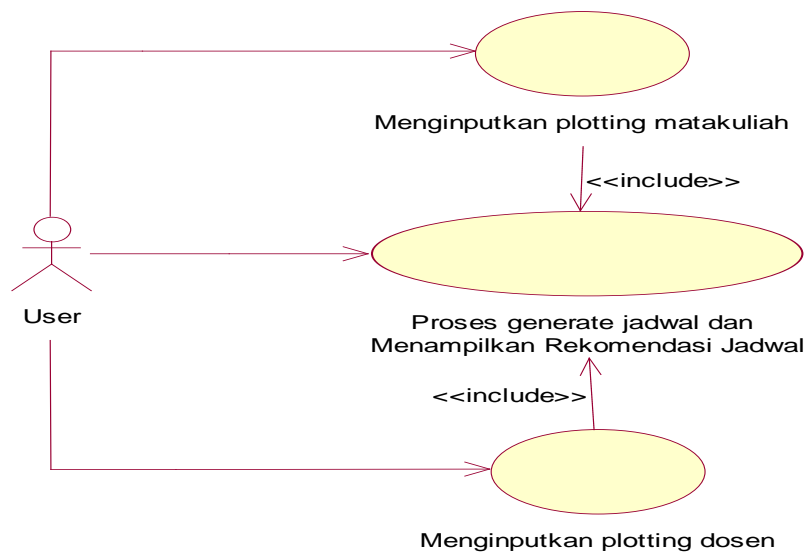

Untuk dapat melakukan proses generate jadwal maka user diharuskan untuk menginputkan plotting matakuliah dan input plotting dosen.

\section{B. Pengelolaan Data}

Pengelolaan Data sangat dibutuhkan pada setiap sistem, tidak terkecuali bagi aplikasi ini. Pada aplikasi ini pengelolaan data menggunakan aplikasi database SQLServer. Berikut adalah gambar Conceptual Data Modelling dari aplikasi ini.

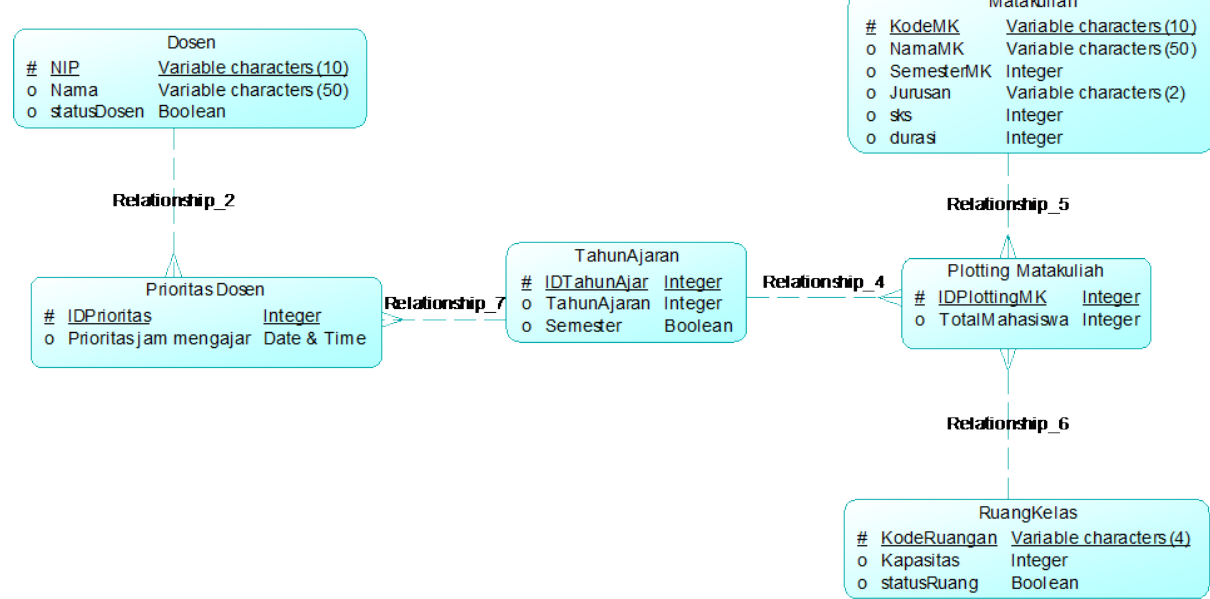




\section{Plotting Matakuliah}

Plotting matakuliah adalah proses yang menunjukan hubungan antara matakuliah dengan ruang kelas dan tahun ajaran. Hal ini berguna untuk mengatur penempatan ruangan serta penempatan matakuliah pada satu semester.

\section{Prioritas Dosen}

Prioritas Dosen adalah proses yang menunjukkan hubungan antara dosen dengan tahun ajaran. Hal ini berguna untuk mengatur jadwal kuliah dengan jam yang tersedia oleh dosen tersebut. Dalam hal ini dosen yang dimaksud adalah dosen tidak tetap. Tetapi dosen tetap juga dapat mengatur jadwal mereka sesuai dengan jam mereka.

\section{E. Hasil Penjadwalan}

Berikut merupakan contoh dari hasil penjadwalan yang telah dilakukan.

\begin{tabular}{|c|c|c|c|c|c|}
\hline Hari & Jam & Kode MataKuliah & MataKuliah & Dosen & Ruangan \\
\hline Senin & $\begin{array}{l}8: 00: 00 \\
\text { AM - } \\
\text { 10:30:00 } \\
\text { AM }\end{array}$ & TI1208011 & $\begin{array}{l}\text { Logika } \\
\text { Matematika }\end{array}$ & $\begin{array}{l}\text { Dwina Nur } \\
\text { Widayanti, } \\
\text { M.Si }\end{array}$ & B201 \\
\hline Senin & $\begin{array}{l}8: 00: 00 \\
\text { AM - } \\
9: 40: 00 \\
\text { AM }\end{array}$ & PK9004011 & $\begin{array}{l}\text { Komunikasi } \\
\text { Interpersonal }\end{array}$ & $\begin{array}{l}\text { Yovita } \\
\text { Asterina } \\
\text { Gunawan, } \\
\text { S.Psi. }\end{array}$ & B203 \\
\hline Senin & $\begin{array}{l}8: 00: 00 \\
\text { AM - } \\
\text { 10:30:00 } \\
\text { AM }\end{array}$ & PK9006011 & Leadership & $\begin{array}{l}\text { Wiria } \\
\text { Chandra, } \\
\text { S.Kom. MSc }\end{array}$ & $\mathrm{A} 303$ \\
\hline
\end{tabular}

\section{KESIMPULAN DAN SARAN}

\section{A. Kesimpulan}

Dalam pembuatan aplikasi Rekomendasi Jadwal Perkuliahan Memanfaatkan Algoritma Genetika ini penulis dapat mengambil beberapa kesimpulan antara lain:

- Algoritma Genetik dapat memberikan solusi bagi masalah penyusunan jadwal secara otomatis

- Penelitian ini dapat memberikan hasil beberapa jadwal rekomendasi yang bervariasi, berbanding lurus dengan banyaknya individu dan iterasi yang digunakan. Dan bagi BAAK IKADO rekomendasi jadwal ini dapat menjadi solusi alternatif dalam menyusun jadwal perkuliahan yang sesuai dengan kebutuhan IKADO sendiri, sehingga memudahkan kerja BAAK IKADO. 


\section{B. Saran}

Saran yang berguna dalam pengembangan sistem lebih lanjut yaitu:

- Perancangan aplikasi dapat dikembangkan lebih lanjut dengan mempercepat proses genetik misalnya dengan mentuning kembali gen dan allele.

- Perancangan struktur data yang lebih simpel pada sisi database sehingga memudahkan dalam pengolahan data pada saat proses genetik.

\section{REFERENSI}

[1] Arindam Chauduri dan Kajal De. Fuzzy Genetic Heuristic for University Course Timetable Problem. (2011)

[2] Eiben, Agoston E. dan J.E. Smith. Introduction to Evolutionary Computing. (2008)

[3] F. Scott Barker. Database Programming with Visual Basic .NET and ADO. NET: Tips, Tutorials, and Code. (2002)

[4] Gen, Mitsuo dan Runwei Cheng. Genetic Algorithm and Engineering Optimization.(2008)

[5] Jeffrey W. Herrmann dan Chung-Yee Lee. Solving a Class Scheduling problem with a Genetic Algorithm. (1994)

[6] Quatrani, Terry. Visual Modeling with Rational Rose 2002 and UML. (2003)

[7] Sivandam, S.N. dan S.N. Deepa. Introduction to Genetic Algorithms. (2008)

[8] Tapan P. Bagchi. Multiobjective Scheduling by Genetic Algorithms. (1999)

[9] Wiga Ayu Puspaningrum, Arif Djunaidy, dan Retno Aulia Vinarti Penjadwalan Mata Kuliah Menggunakan Algoritma Genetika di Jurusan Sistem Informasi ITS. (ITS 2013).

[10] Microsoft Visual Studio History. Tersedia di :

$<$ http://msdn.microsoft.com/library/vstudio >

[11] Theory of Natural Selection. Tersedia di :

< http://www.biology-online.org/2/10_natural_selection.htm.>

[12] White-box testing. Tersedia di :

$<$ http://span.depkeu.go.id/pengujian-sakti-strategi-dan-metode > 